\title{
Biosorption of Azo dyes by spent Rhizopus arrhizus biomass
}

\author{
Neeta A. Salvi ${ }^{1}$ S. Chattopadhyay ${ }^{1}$
}

Received: 28 January 2016/ Accepted: 25 April 2016/Published online: 9 May 2016

(c) The Author(s) 2016. This article is published with open access at Springerlink.com

\begin{abstract}
In the present study, spent Rhizopus arrhizus biomass was used for the removal of six azo dyes from aqueous solutions. The dye removal capacity of the biomass was evaluated by conducting batch tests as a function of contact time, biomass dosage, $\mathrm{pH}$ and initial dye concentrations. The pseudo-second-order kinetic model fitted well with the experimental data with correlation coefficients greater than 0.999 , suggesting that chemisorptions might be the rate limiting step. The equilibrium sorption data showed good fit to the Langmuir isotherm model. Among the six dyes tested, the maximum monolayer adsorption capacity for fast red $\mathrm{A}$ and metanil yellow was found to be 108.8 and $128.5 \mathrm{mg} / \mathrm{g}$, respectively. These encouraging results suggest that dead Rhizopus arrhizus biomass could be a potential biomaterial for the removal of azo dyes from aqueous dye solution.
\end{abstract}

Keywords Rhizopus arrhizus · Spent biomass · Biosorption · Azo dyes · Adsorption isotherms

\section{Introduction}

Azo dyes are characterized by the presence of one or more azo $(-\mathrm{N}=\mathrm{N}-)$ bonds. Almost $10^{9} \mathrm{~kg}$ of dyes are produced annually of which about $70 \%$ represent azo dyes. Most of them, and their degraded products, such as aromatic amines, are also potential health hazards because of their mutagenic and carcinogenic properties (Crini 2006;

Neeta A. Salvi

nasalvi@barc.gov.in

1 Bio-Organic Division, Bhabha Atomic Research Centre, Trombay, Mumbai 400 085, India
Zaharia et al. 2012; Zhang and Ma 2013). Azo dyes are bright in colours with high intensity and have fair to good fastness properties. In addition, they are available in wide range and have low manufacturing costs. Hence, these dyes are used in textile, pharmaceuticals, plastics, leather, paper, mineral oils, wax industries and even in selected food items and cosmetics. In the dyeing process, $\sim 10 \%$ of dye is lost and released in wastewater, making the waterbodies coloured and contaminated with significant amounts of residual dyes (Anjaneya et al. 2013; Olukanni et al. 2009; Stolz 2001). Colour is the first visible pollution in water bodies which hampers its aesthetic nature, cuts-off sunlight penetration, disturbs photosynthesis and causes chronic and acute toxicity (Aksu et al. 2007; Gupta and Suhas 2009). The incorrect disposal of these effluents is a major environmental concern and of great threat to human and animal health. It is, therefore, mandatory to treat the dye bath effluents prior to discharge in the surrounding waterbodies. In addition, the treatment should be economic and ecofriendly.

Removal of azo dyes from aqueous effluents is difficult, as they are stable when they exposed to light and heat. Most of the dyes are biologically non-degradable because of their complex structures (Swamy and Ramsay 1999; Maas and Chaudhari 2005; Couto 2009). In general, chemical and physical treatments, such as coagulation, oxidation, ozonation, filtration, precipitation, membrane filtration and adsorption, have been used for the removal. Some of them are effective but suffer from limitations, such as high-energy costs, high-sludge production, etc. (Supaka et al. 2004; Hai et al. 2007). Amongst other methods, activated carbon is the most preferred adsorbent to remove the traces of colour by the virtue of its easy operation (Foletto et al. 2012). However, high operational cost has limited its usage (Gupta and Suhas 2009). Many 
research groups have explored the use of biosorbents derived from microbial biomasses, including algae, bacteria, and fungi as well as agricultural and industrial byproducts (Crini 2006). The dead and dried biomaterials are preferred, as they gave comparable performance with easy recovery of sorbet without polluting the environment by releasing toxic by-products during operation (Tigini et al. 2011). Dead biomass is not affected by toxic waste or chemicals and does not require nutrients. They can thereafter be stored for longer periods at room temperature with little risk of putrefaction making them easy to use and transport. They are also available as a waste product from established industrial processes (Kapoor and Viraraghavan 1998). Agricultural and industrial waste materials could also be used as low-cost adsorbents, which makes the process economic but also helps in the disposal of solid waste (Sadafa and Bhatti 2016; Sadafa et al. 2015a, b; Bhatti et al. 2015; Yang et al. 2013; Wang and Chen 2009).

The overall economics of the biosorption process is mainly influenced by the cost of procuring/growing the biomass. The spent $R$. arrhizus biomass used in our study was obtained virtually free of cost from biotransformation studies done for the asymmetric synthesis of chiral carbinols using fungus $R$. arrhizus (Salvi and Chattopadhyay 2011, 2008). This material was found to be an effective bio-material for the removal of trivalent actinides and fission products from low-level waste streams generated in the PUREX process (Dhami et al. 1998a, b, 2002; Tripathi et al. 2011). This biomass can also used as a compost to enrich the soil conditions. The preliminary studies showed a better germination of maize plant and also supported the growth of plant. Further studies on soil properties are in progress. In addition, this biomass being dead is also flexible to environmental conditions and toxicant concentrations, thus promotes eco-friendliness. In particular, fungal biomass is attractive, because many food and industrial fermentation processes can provide a cheap and constant supply of fungal biomass. For example, the lactic acid and fungal biomass by Rhizopus arrhizus were produced from food processing waste streams in a single-stage fermentation process (Jin et al. 2005). Therefore, the use of spent $R$. arrhizus biomass was found to be resourceful considering its wide availability, inexpensive sourcing, processing and multi-pronged utility. Furthermore, it also addresses the concern of its disposal to some extent, thereby adding value to excel the process. Hence, its potential towards wastewater treatment was studied. In this regard, the biosorption of six azo dyes viz., amaranth, fast red $\mathrm{A}$, congo red, tartrazine, metanil yellow and sunset yellow FCF were investigated by spent $R$. arrhizus biomass under varying operating parameters, such as contact time, biomass amount, $\mathrm{pH}$ and initial dye concentrations. The outcome of this study is presented in this communication.
These azo dyes are widely used for colouring natural and synthetic fibers, paper, wood, leather, cosmetics, food and pharmaceuticals, especially the shells of medicinal capsules and syrups (Perez-Urquiza and Beltran 2000; Shahmoradi et al. 2011; Anjaneya et al. 2013, 2011). Due to their widespread use and low biodegradability (Avramescu et al. 2009), they induce a significant threat to human health and ecological systems. Dye amaranth is suspected to be a mutagenic, carcinogenic and genotoxic agent, and has been banned or restricted in several countries (Jabeen et al. 2013; Jadhav et al. 2013; Karkmaz et al. 2004). Exposure to the dye congo red has been known to cause allergic reactions (Bhattacharyya and Sharma 2004; Pavan et al. 2008). It acts as a skin, eye and gastrointestinal irritant. It affects blood factors, such as clotting, and induces drowsiness and respiratory problems (Demirbas 2009). Due to the wide applicability of dye tartrazine in various industrial processes and its hydrophilic nature, its presence can be noticed as a yellow menace in effluents. It is considered to be highly toxic for humans as it acts as hyperactivity (Lockey 1977; Bhatia 2000). It also causes asthma, migraines, eczema, thyroid cancer and other behavioural problems (Pohl et al. 1987; Moutinho et al. 2007; Gautam et al. 2015). On oral consumption, dye metanil yellow causes toxic methaemoglobinaemia (Sachdeva et al. 1992) and cyanosis (Chandro and Nagaraja 1987) in humans, while skin contact results into allergic dermatitis (Hausen 1994). It also has tumour-producing effects and can also create intestinal (Ramachandani et al. 1997) and enzymic (Das et al. 1997) disorders in human body. Though it is not mutagenic but can alter the expression of genes (Gupta et al. 2003). Dye sunset yellow itself may be responsible for causing an allergic reaction in people with an aspirin intolerance resulting in various symptoms, including gastric upset, diarrhoea, vomiting, urticaria and swelling of the skin (Peiperl et al. 1995; Poul et al. 2009). Thus, dye pollution has a direct impact on human health and ecosystem. This causes a lot of concerns regarding its use and, therefore, its removal from aqueous solutions is essential. These results might be useful in ascertaining optimum conditions for the removal of dyes from industrial waste and also to establish the fact that the spent $R$. arrhizus biomass could be a potential biomass for the removal of these dyes from industrial effluents.

\section{Materials and methods}

\section{Biomass}

Spent Rhizopus arrhizus (wild type) biomass was obtained as a byproduct from the biotransformation studies. This waste biomass was then washed with distilled water and 
hot acetone (AR grade), dried in the oven to a constant weight, ground and sieved to particle size of 420 microns. The dry biomass was stored at room temperature and used for the sorption studies.

\section{Instrumentation}

Agitation was carried out on DBK-digital orbital shaker. The UV absorbance was measured on Helios $\alpha$ Spectronic Unicam spectrophotometer. The elemental analyzer, Vario Micro Cube, Elementar, Germany was used for elemental analysis. The IR spectra were recorded on the FTIR-4100 model, Jasco, Japan. The optical images were captured with a charge-coupled device, Axiocam MRC (Zeiss), camera at $600 \times$ and $1500 \times$ (oil immersion) magnification on Carl Zeiss Axioscop microscope.

\section{Dyes}

Six widely used commercial azo dyes, viz., Amaranth (1), Fast red A (2), Congo red (3), Tartrazine (4), Metanil yellow (5) and Sunset yellow FCF (6) (Table 1) were used as is.

\section{Preparation of dye solutions}

The stock solutions were prepared by dissolving $1.0 \mathrm{~g}$ of each dye separately in $1 \mathrm{~L}$ distilled water. The working solutions for each dye (concentration range $25-1000 \mathrm{mg} / \mathrm{L}$ ) were prepared by successive dilutions of the corresponding stock solutions. The mixed dyes solution was prepared with equal concentrations of each of the six dyes (1-6) in the solution to give final concentrations between 25 and $1000 \mathrm{mg} / \mathrm{L}$.

\section{Batch experiments}

Batch experiments were conducted to evaluate the effect of various parameters, such as contact time, biomass amount, $\mathrm{pH}$ and initial dye concentration on the adsorptive removal of these dyes. For optimization, $25 \mathrm{~mL}$ dye solution was taken in $100 \mathrm{~mL}$ conical flask, and agitation was carried out at $100 \mathrm{rpm}$, at ambient temperature without $\mathrm{pH}$ adjustment (natural $\mathrm{pH}$ 5.5-6.5). The aqueous layer was then filtered through a Whatman filter paper no. 1 , and the absorbance of the filtrate was measured at the respective dye maxima. The measured absorbance values of solutions
Table 1 General data and chemical structures of six azo dyes used in this study

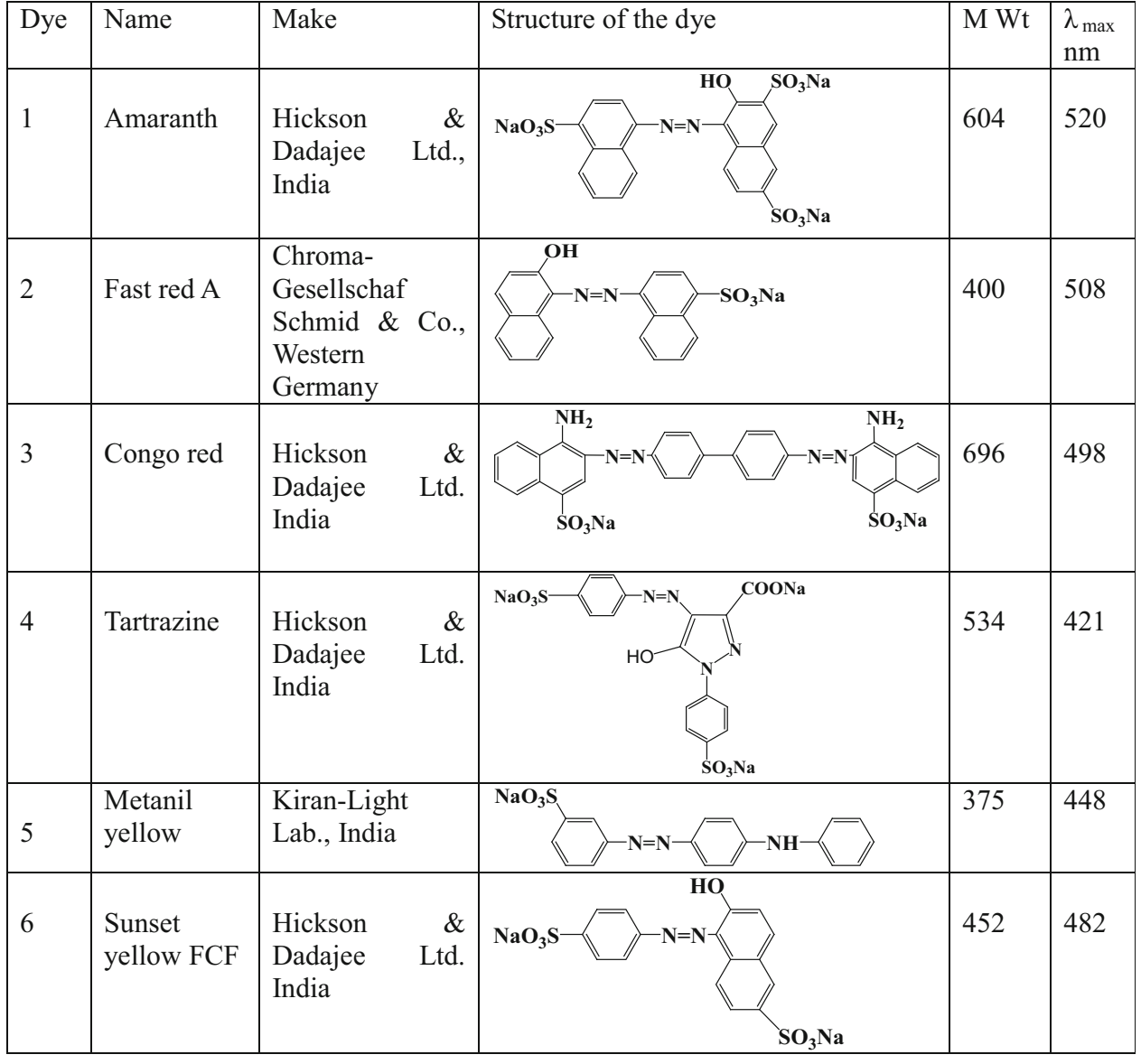


before and after equilibrium were used to calculate the percent colour removal (\% CR) by the biomass using Eq. (1), where Ai and Af are the initial and final absorbance of dye. Data represent an average of three independent experiments, and error bars indicate the standard error of the mean.

$\% \mathrm{CR}=\frac{\mathrm{Ai}-\mathrm{Af}}{\mathrm{Ai}} \times 100$

\section{Optimization of sorption conditions}

The biosorption conditions were optimized for each dye solution of concentration $100 \mathrm{mg} / \mathrm{L}$ (except the concentration effect). The effect of biosorption was measured in the time range of 5-360 min using $250 \mathrm{mg}$ of biomass (except the dose effect). This optimized contact time was further used to find out the effect of biomass amount in the biomass range between 25 and $250 \mathrm{mg}$. The effect of $\mathrm{pH}$ on the biosorption was analyzed over the range of $\mathrm{pH} 2-10$. The $\mathrm{pH}$ was adjusted using $0.1 \mathrm{~N} \mathrm{HCl}$ or $\mathrm{NaOH}$ solutions.

\section{Effect of initial dye concentration}

The effect of initial dye concentration was studied in the concentration range $25-1000 \mathrm{mg} / \mathrm{L}$ at optimized conditions. The dye uptake per gram of biomass was calculated using Eq. (2), where $q$ is the dye uptake $(\mathrm{mg} / \mathrm{g}), V(\mathrm{~L})$ is the volume of dye solution, $\mathrm{Ci}$ and $\mathrm{Cf}$ are the initial and final concentrations of dye in $\mathrm{mg} / \mathrm{L}$ and $M$ is the dry weight of the biomass in gram.

$q=\frac{(C \mathrm{i}-C \mathrm{f}) V}{M}$

\section{Adsorption kinetics}

In batch experiments, the rate of sorption of a dye on the biomass was evaluated using different kinetic models: the pseudo-first-order, pseudo-second-order kinetics and intraparticle diffusion models. The pseudo-first-order Lagergren model (Lagergren 1898) is expressed by Eq. (3), where $q$ and $\mathrm{qt}(\mathrm{mg} / \mathrm{g})$ are the amount of dye adsorbed at equilibrium time and time $t(\mathrm{~min})$, respectively. $k_{1}(\mathrm{mg} / \mathrm{g} . \mathrm{min})$ is the Lagergren rate constant of the pseudo-first-order adsorption, calculated from the slope and $\log q$ from the intercept of the plot $\log (q-\mathrm{qt})$ against $t$.

$\log (q-q t)=\log q-\frac{k_{1}}{2.303} t$

The pseudo-second-order kinetic model developed by Ho et al. (Ho and McKay 1999; Ho and Wang 2004) is expressed by Eq. (4), where $t$ is the contact time (min), $q$ and $\mathrm{qt}(\mathrm{mg} / \mathrm{g})$ are the amounts of dye adsorbed at equilibrium and at time $t$, respectively, $k_{2}$ is the pseudo- second-order constant $(\mathrm{g} / \mathrm{mg} \min )$ and $k_{2} q^{2}=h$ is the initial adsorption rate $(\mathrm{mg} / \mathrm{g} \mathrm{min})$. The second-order rate constants $k_{2}$ and $q$ were calculated from the intercept and slope of the plot of $t / q$ against $t$.

$\frac{t}{q t}=\frac{1}{k_{2} q^{2}}+\frac{t}{q}$

The intra-particle diffusion model (Weber and Morris 1962) is expressed by Eq. (5), where qt $(\mathrm{mg} / \mathrm{g}$ ) is the amount of dye adsorbed, $k_{\mathrm{p}}\left(\mathrm{mg} / \mathrm{g} \min ^{1 / 2}\right)$ is a rate constant and $C(\mathrm{mg} / \mathrm{g})$ is the intra-particle diffusion constant. A plot of qt and the square root of the time give the rate constant (slope of the plot) and the intra-particle diffusion constant, i.e., intercept of the line which is directly proportional to the boundary layer thickness.

$\mathrm{qt}=k_{\mathrm{p}} t^{1 / 2}+C$

\section{Adsorption isotherms}

The experimental equilibrium data were analyzed using Langmuir (Langmuir 1918) and Freundlich (Freundlich and Heller 1939) models.

The linear form of Langmuir isotherm is represented by Eq. (6), where $\mathrm{Cf}(\mathrm{mg} / \mathrm{L})$ is the concentration of dye remaining in the solution at equilibrium, $q(\mathrm{mg} / \mathrm{g})$ is the amount of dye adsorbed per-unit weight of biomass at equilibrium, $q_{\mathrm{m}}(\mathrm{mg} / \mathrm{g})$ is the maximum sorption capacity corresponding to monolayer sorption on the surface and $K_{\mathrm{L}}$ $(\mathrm{L} / \mathrm{g})$ is a Langmuir constant indicating affinity of dye towards the biomass.

$\frac{C f}{q}=\frac{1}{q_{\mathrm{m}} K_{\mathrm{L}}}+\frac{C f}{q_{\mathrm{m}}}$

$R_{\mathrm{L}}$ is a dimensionless separation factor (McKay et al. 1982) which is an essential characteristic of Langmuir equation defined by Eq. (7), where $\mathrm{Ci}(\mathrm{mg} / \mathrm{L})$ is the initial dye concentration. The value of $R_{\mathrm{L}}$ indicates the type of isotherm to be either unfavourable $\left(R_{\mathrm{L}}>1\right)$, linear $\left(R_{\mathrm{L}}=1\right)$, favourable $\left(0<R_{\mathrm{L}}<1\right)$ or irreversible $\left(R_{\mathrm{L}}=0\right)$.

$R_{\mathrm{L}}=\frac{1}{1+K_{\mathrm{L}} C i}$

The linear form of Freundlich isotherm is shown by Eq. (8), where $K_{\mathrm{F}}(\mathrm{mg} / \mathrm{g})$ and $1 / n$ (dimensionless) are Freundlich isotherm constants that indicate the adsorption capacity and the adsorption intensity, respectively, and also indicate the favourability of the adsorption process.

$\log q=\log K_{\mathrm{F}}+1 / n \log C f$

\section{Effect of salt concentration}

This experiment was carried out using the mixed azo dye solution of concentration, 100 and $200 \mathrm{mg} / \mathrm{L}$ under 
optimized condition. The salt $\mathrm{NaCl}$ concentration was varied for $0-5 \% \mathrm{w} / \mathrm{v}$, and the extent of biosorption was assayed by spectrophotometer.

\section{Desorption studies}

Several dye loaded biomass samples were obtained from the adsorption experiments carried out with mix azo dye solution of concentration $100 \mathrm{mg} / \mathrm{L}$ under optimized condition. The dye-loaded biomasses were agitated separately with $25 \mathrm{~mL}$ of distilled water, $0.01 \mathrm{~N} \mathrm{HCl}, 0.1 \mathrm{~N} \mathrm{HCl}, 0.01 \mathrm{~N} \mathrm{NaOH}$ and $0.1 \mathrm{~N} \mathrm{NaOH}$ solutions for $15 \mathrm{~min}$. The cell debris was removed by filtration, and the \% colour desorption was estimated by spectrophotometer.

\section{Result and discussion}

\section{Biomass surface characterization}

The C, H, N, S analysis of Rhizopus arrhizus dead biomass is preliminary analysed using the graphite $120 \mathrm{~S}$ combustion method. As presented in Table 2, the percentage of organic carbon and nitrogen was found to be 44.8 and 5.2, respectively.

The IR spectral analysis of native and dye-loaded $R$. arrhizus biomass is presented in Fig. 1. The spent biomass showed the presence of amino, carboxyl, hydroxyl and phosphate groups on the biomass. The broad band at $3274 \mathrm{~cm}^{-1}$ indicated the existence of amine groups. The characteristic bands at 2923 and $2843 \mathrm{~cm}^{-1}$ showed the presence of alkyl chains. A band at $1710 \mathrm{~cm}^{-1}$ can be attributed for $\mathrm{C}=\mathrm{O}$ of the carboxyl groups of amino acids. The amide band was primarily a $\mathrm{C}=\mathrm{O}$ stretching mode that was centered at $1624 \mathrm{~cm}^{-1}$. The combination of $\mathrm{N}-\mathrm{H}$ and $\mathrm{C}-\mathrm{N}$ stretching appeared near $1531 \mathrm{~cm}^{-1}$, and the more complex amide band was located near $1372 \mathrm{~cm}^{-1}$. Peaks at $1452-1408 \mathrm{~cm}^{-1}$ can be attributed to $\mathrm{COO}^{-}$of the carboxylate groups present in the biomass. The strong band at $1021 \mathrm{~cm}^{-1}$ was due to the $\mathrm{C}-\mathrm{O}$ bond, a characteristic peak for polysaccharides. The absorption bands at 1144 and $941 \mathrm{~cm}^{-1}$ were for $\mathrm{P}-\mathrm{OH}$ and $\mathrm{P}-\mathrm{O}$ stretching, respectively, indicating the presence of phosphate groups in the biomass. All these fungal cell wall components may interact with the dye molecules via chemical interactions, electrostatic attractions and weak physical forces, such as hydrogen bonding and Van der Waals interactions, between aromatic

Table 2 Amount of \% organic carbon, hydrogen, nitrogen and sulphur contained in Rhizopus arrhizus spent biomass

\begin{tabular}{lllllll}
\hline Biomass & $\mathrm{C}(\%)$ & $\mathrm{H}(\%)$ & $\mathrm{N}(\%)$ & $\mathrm{S}(\%)$ & $\mathrm{C} / \mathrm{N}$ ratio & $\mathrm{C} / \mathrm{H}$ ratio \\
\hline R. arrhizus & 44.8 & 6.9 & 5.2 & 0.1 & 8.6 & 6.5 \\
\hline
\end{tabular}

Fig. 1 FTIR spectra of spent Rhizopus arrhizus biomass before and after dye sorption

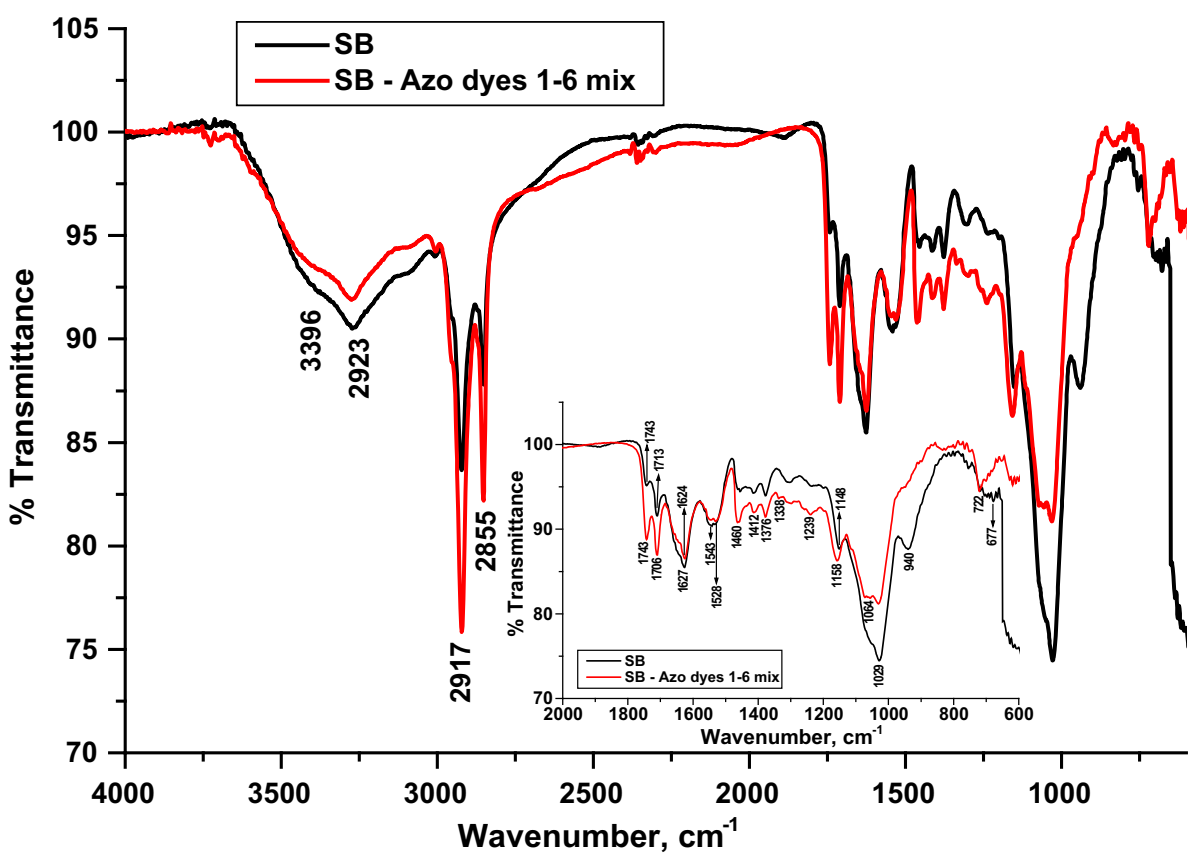

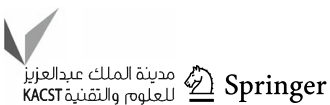



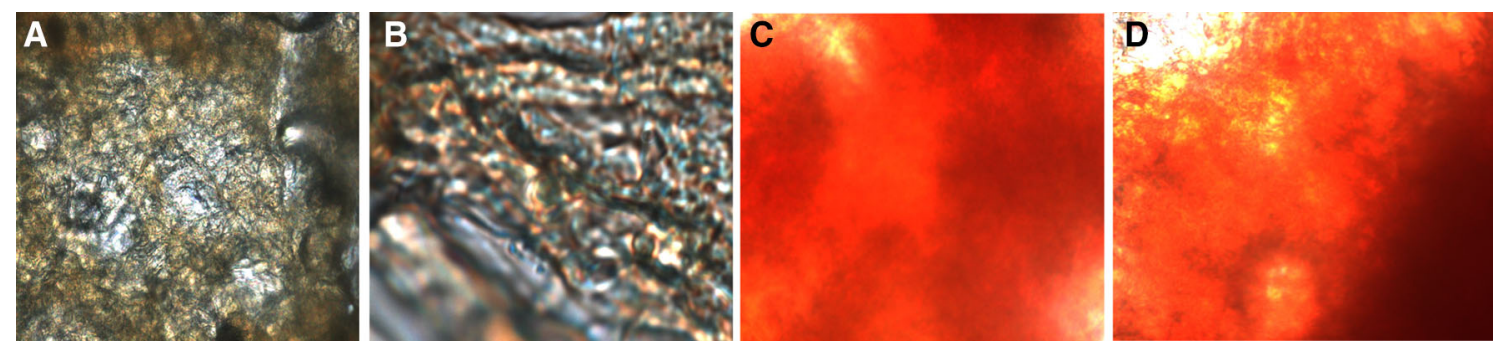

Fig. 2 Optical microscopic image of $R$. arrhizus biomass before $(\mathbf{a} \times 600, \mathbf{b} \times 1500$, oil immersion $)$ and after Azo dyes adsorption $(\mathbf{c} \times 600$, d $\times 1500$, oil immersion) magnification

rings of dye molecules and the polysaccharide of the biomass (Blackburn 2004). The spectrum of the dye loaded biomass showed slight shifting of peaks from their position with alteration in intensity indicating the involvement of some functional group in the adsorption of dye ions on the surface of the biomass.

The surface physical morphology of the biomass before and after dye biosorption was evaluated by optical microscopic images. As presented in Fig. 2, the native biomass showed some cavities and micro-pores on the rough surface (Fig. 2a, b). After the biosorption process, the biomass appeared to be rough with slight changes, as shown in Fig. 2c and d.

\section{Effect of contact time}

The removal of azo dyes by the biomass as a function of contact time is shown in Fig. 3. Speedy decolourization of all dye solutions was observed within initial 15-20 min. After equilibrium, the sorption process became less significant and remained nearly constant. The rapid adsorption process signified a high degree of affinity of biomass for these dyes. The colour removal efficiency was found to be varied from 85 to $99 \%$. The maximum \% CR for dye 3 and 2 was achieved within 30 and 60 min, respectively. For dyes 1,5 and mixed azo dye solution, the maximum \% CR was obtained within $120 \mathrm{~min}$, while for dye 4 and 6 , it took $240 \mathrm{~min}$. This optimum contact time of each dye was kept constant in further studies for respective dye.

\section{Effect of biomass amount}

The effect of biomass concentration on \% CR is summarized in Fig. 4. It was observed that the dye removal efficiency increased with an increase in the biomass dosage from 100 to $250 \mathrm{mg}$ due to the availability of more sorption sites (Garg et al. 2003). The extent of colour removal varied from dye to dye, as a possible result of the structural variation of dyes. Dye 2 and dye 3 showed $>95 \%$ colour removal with 100 and $150 \mathrm{mg}$ biomass, respectively, whereas $200 \mathrm{mg}$ biomass was required for dyes 1, 4, 5, 6

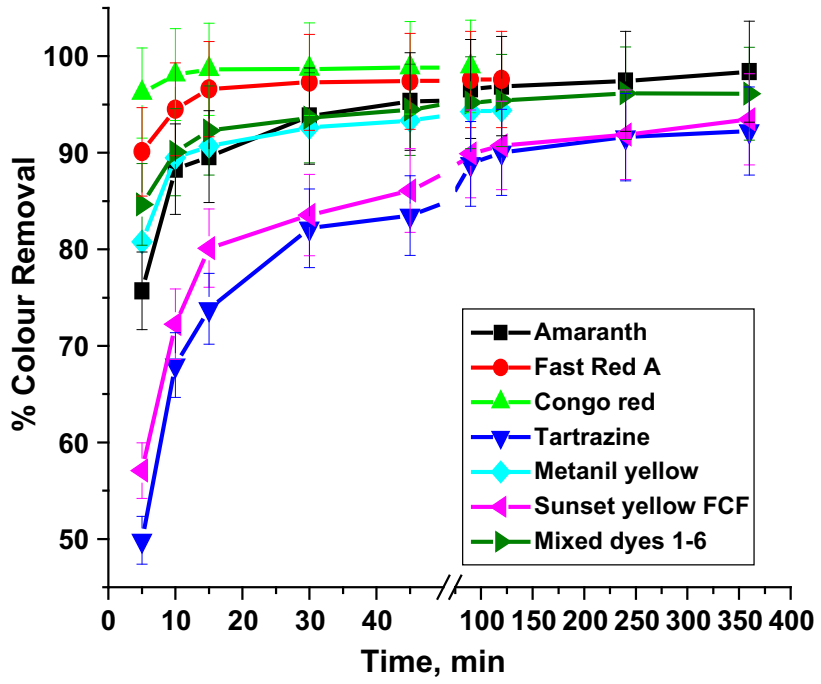

Fig. 3 Effect of contact time on the adsorption of azo dyes by spent $R$. arrhizus biomass [conditions: biomass dose $(250 \mathrm{mg} / 25 \mathrm{~mL}$ dye solution), dye concentration (100 mg/L), agitation speed (100 rpm), ambient temperature, natural $\mathrm{pH}]$

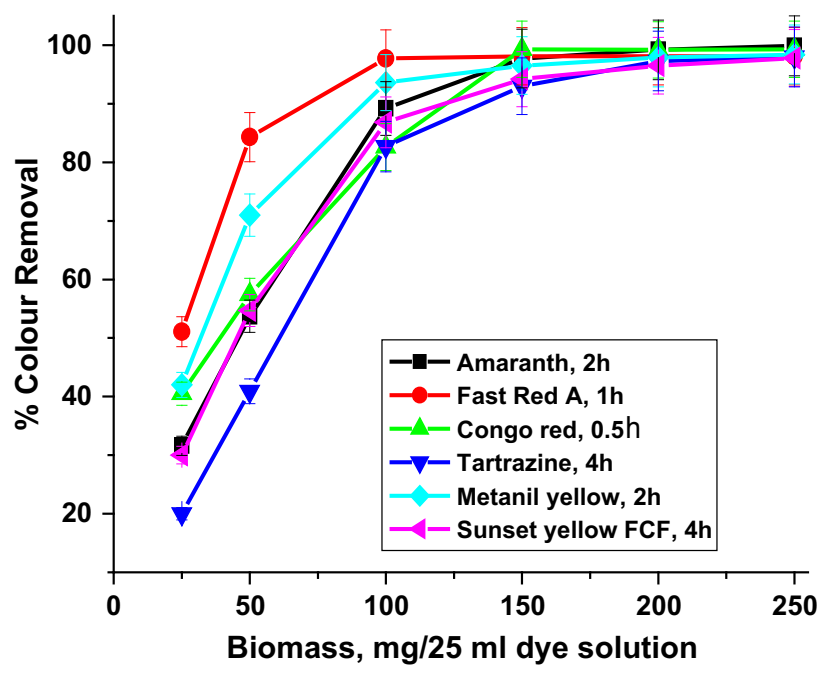

Fig. 4 Effect of biomass amount on the adsorption of azo dyes by spent $R$. arrhizus biomass [conditions: dye concentration (100 mg/L), agitation speed (100 rpm), ambient temperature, natural $\mathrm{pH}$ ] 


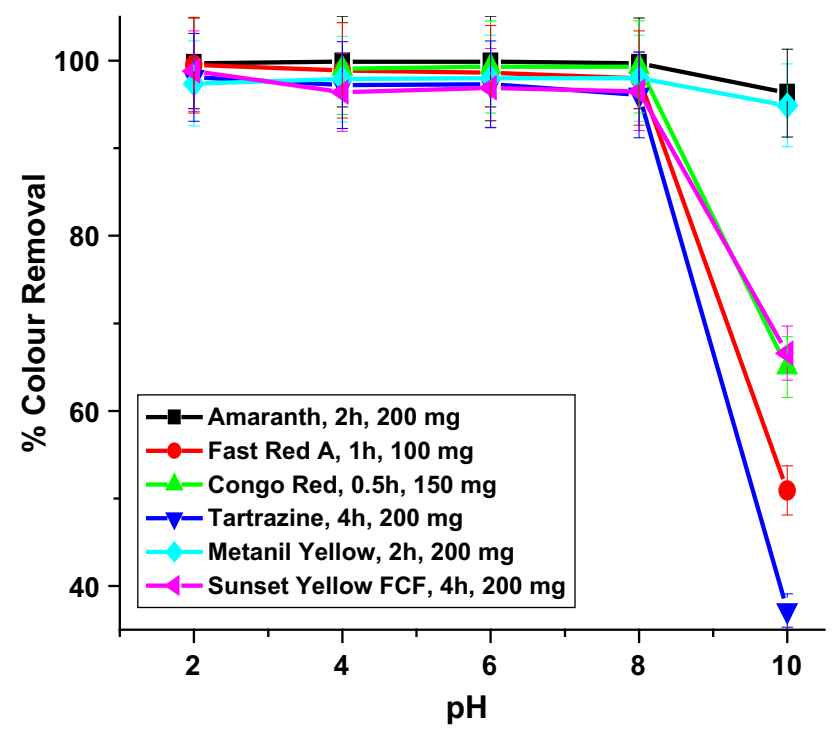

Fig. 5 Effect of $\mathrm{pH}$ on the adsorption of azo dyes by spent $R$. arrhizus biomass [conditions: dye concentration $(100 \mathrm{mg} / \mathrm{L})$, agitation speed $(100 \mathrm{rpm})$, ambient temperature]

and mixed 1-6 dye solution for maximum colour removal and kept constant for further studies. Beyond this there was no change in the dye removal efficiency due to the establishment of equilibrium between the dye molecules and the biomass (Sudha Bai and Abraham 2001). These data support the effectiveness of biomass as a sorbent for the removal of azo dyes from aqueous solution (Farah et al. 2007; Hamdaoui et al. 2008).

\section{pH effect}

As depicted in Fig. 5, the adsorption of all six dyes showed maximum colour removal (97-99\%) up to $\mathrm{pH} 8$, and thereafter, a significant decrease was noticed. At higher $\mathrm{pH}$, negatively charged surface sites were unfavourable for dye adsorption due to possible electrostatic repulsion (Arami et al. 2006; Mall et al. 2005). Therefore, the favoured $\mathrm{pH}$ range for the adsorption of these azo dyes was up to $\mathrm{pH} 8$. The aqueous solutions of all these dyes have natural $\mathrm{pH}$ $\sim 6$, and at this $\mathrm{pH}$, maximum adsorption was observed. Further sorption experiments were carried out at their natural $\mathrm{pH}$. A pH lower than 4.0 could not be used for Congo red, as at this $\mathrm{pH}$, the colour of this dye changes due to its structural characteristics.

\section{Effect of initial dye concentration}

The effect of the initial dye concentration on the adsorption capacity is illustrated in Fig. 6. The adsorption capacity increased with an increase in dye concentration. At low initial dye concentration, the complete removal of dye was

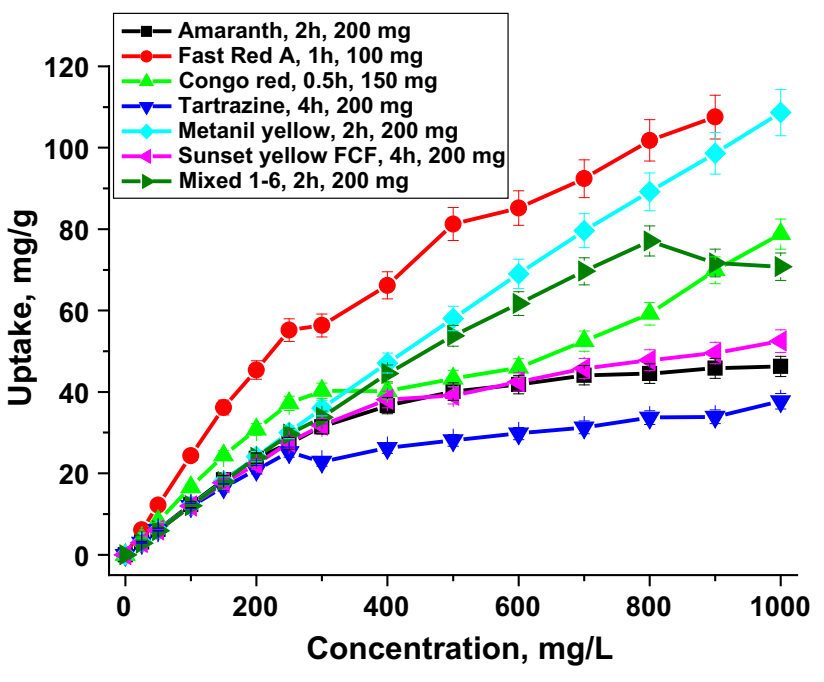

Fig. 6 Effect of initial dye concentration on the uptake of azo dyes by spent $R$. arrhizus biomass [conditions: agitation speed (100 rpm), ambient temperature, natural $\mathrm{pH}]$

noticed due to the availability of sufficient adsorption sites to adhere with the dye molecules. The increase in the dye concentration with limited adsorption sites caused a decrease in the colour removal efficiency, but the participation of more dye molecules increased uptake.

\section{Kinetic studies}

Kinetic study provides adsorption mechanism and also predicts the rate at which a pollutant is removed from the waste solution. The rate-determining steps for the adsorption of azo dyes on fungal biomass were examined using different kinetic models (the pseudo-first-order, pseudosecond-order and intra-particle diffusion model), and their regression coefficients were compared.

The plots of $\log (q-\mathrm{qt})$ against $t$ of these azo dyes did not show any promising results, as data are scattered and showed deviation from straight line (figure not shown). The correlation coefficient obtained from the pseudo-first-order model was found to be less than that of the pseudo-secondorder model, and the calculated $q$ values were not adequate with the experimental values, suggesting the insufficiency of the pseudo-first-order model for these azo dyes. This indicated a poor fit of the pseudo-first-order model to the experimental data.

A linear plot of t/qt against $t$ for all six azo dyes indicated the best fit with the pseudo-second-order kinetic model (Fig. 7). The values of equilibrium dye uptake $q(\mathrm{mg} / \mathrm{g})$ and equilibrium constant $k_{2}(\mathrm{~g} / \mathrm{mg} \mathrm{min})$ obtained from the slope and intercept are represented in Table 3. The data showed that the linear regression values $\left(R^{2}\right)$ were near to unity, confirming that the sorption data obeyed the

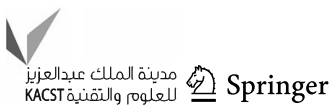




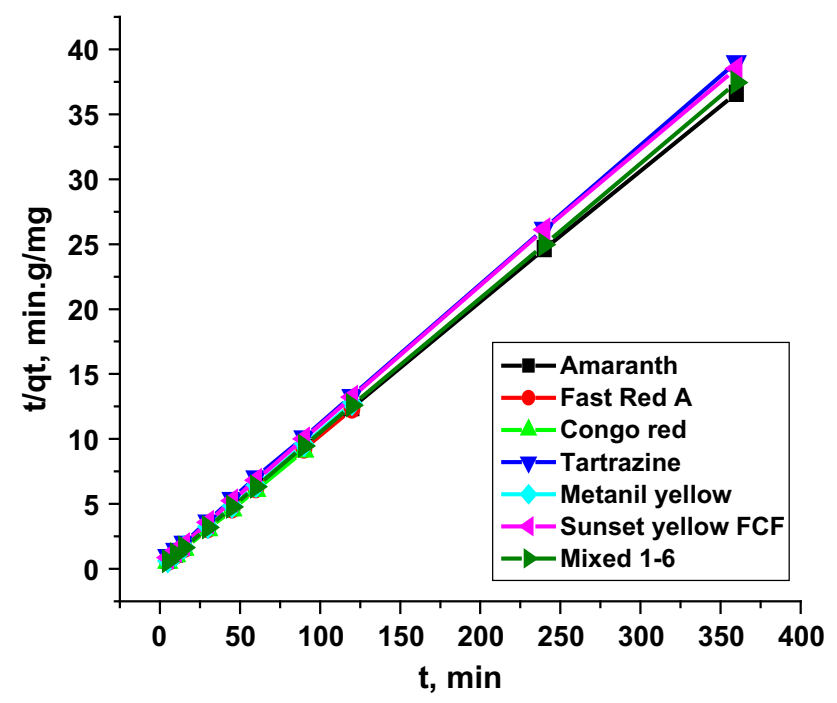

Fig. 7 Pseudo-second-order kinetic plots for azo dyes adsorbed onto spent $R$. arrhizus biomass

pseudo-second-order kinetics signifying that the chemisorptions might be the rate-limiting step.

The experimental data were also analyzed by the intraparticle diffusion kinetic model. According to this model, a plot of qt against $t^{1 / 2}$ should be linear if intra-particle diffusion is involved in the adsorption process and if line passes through origin, the intra-particle diffusion is the rate-controlling step. As shown in Fig. 8, the plots appear as combination of two to more intersecting lines (Wu et al. 2000). The first shaper portion represents the external surface adsorption or instantaneous adsorption. The second linear portion showed gradual adsorption stage, where intra-particle diffusion takes place, that is rate-limiting step. The third step is the final equilibrium stage, where intra-particle diffusion starts to slow down. As the second portion of plot did not pass through the origin, the intraparticle diffusion was not the only rate controlling step, indicating surface adsorption and intra-particle diffusion were likely to take place simultaneously. A similar type of

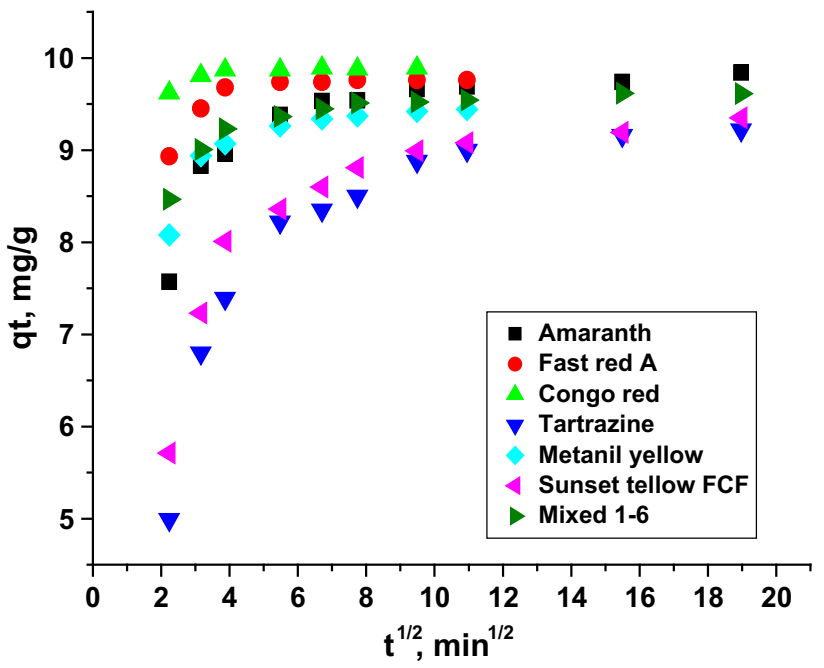

Fig. 8 Intra-particle diffusion plot for mixed azo dye adsorbed onto spent $R$. arrhizus biomass

results has been reported by other workers (Zhan et al. 2013; Yu et al. 2011).

\section{Adsorption isotherms}

Adsorption isotherm is a basic requirement for designing the sorption system. It is used to understand the adsorption process and the interaction between the adsorbent to determine the adsorption capacity.

The Langmuir isotherm model predicts the existence of monolayer coverage of dye onto a homogeneous surface with no interaction among the adsorbed molecules. The plot of equilibrium sorption data as per Langmuir isotherm $(\mathrm{Cf} / q$ against $\mathrm{Cf})$ showed a linear relationship. One of these plots for mixed azo dyes is shown in Fig. 9. The slope and intercept indicated the values of $\mathrm{q} \max$ and $K_{\mathrm{L}}$, and are presented in Table 4. This proved the monolayer sorption of dye on the homogeneous surface of biomass. The calculated $R_{\mathrm{L}}$ values are presented in Fig. 10 and found to be in the range of $0<R_{\mathrm{L}}<1$ for all dye concentrations

Table 3 Pseudo-second-order kinetic parameters of sorption of azo dyes

\begin{tabular}{llllll}
\hline Dyes & Contact time, $\min$ & $R^{2}$ & $q, \mathrm{mg} / \mathrm{g}$ & $k_{2}, \mathrm{~g} / \mathrm{mg} \mathrm{min}$ & Initial rate, $\mathrm{mg} / \mathrm{g}$ min \\
\hline 1 & 120 & 0.999 & 9.78 & 0.078 & 7.45 \\
2 & 60 & 1 & 9.79 & 0.367 & 35.15 \\
3 & 30 & 1 & 9.91 & 0.983 & 96.43 \\
4 & 240 & 0.999 & 9.28 & 0.026 & 2.198 \\
5 & 120 & 1 & 9.50 & 0.138 & 12.47 \\
6 & 240 & 0.999 & 9.29 & 0.035 & 3.05 \\
Mixed 1-6 & 120 & 1 & 9.70 & 0.125 & 11.74 \\
\hline
\end{tabular}




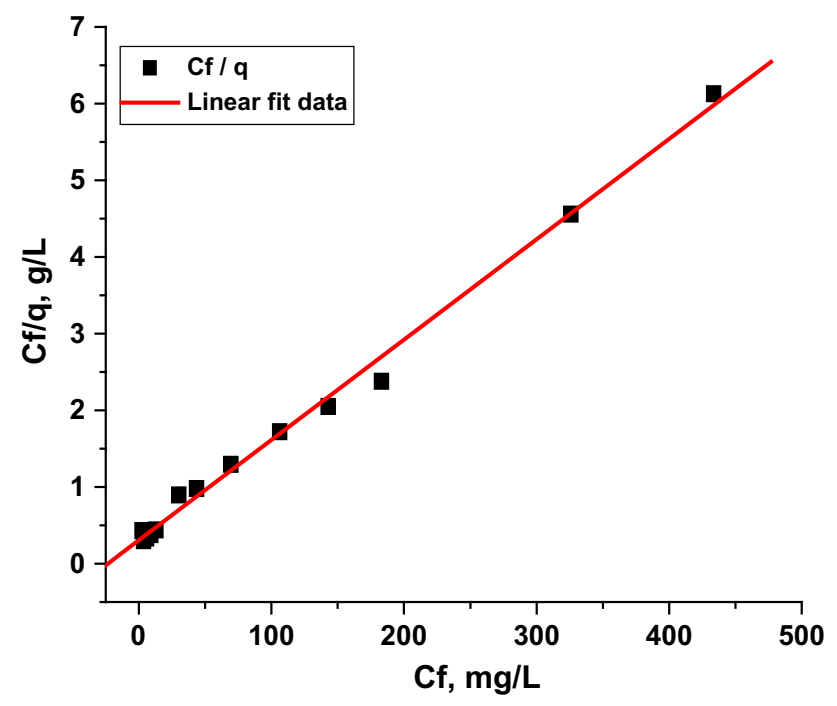

Fig. 9 Langmuir adsorption isotherm of mixed 1-6 azo dyes on spent $R$. arrhizus biomass

studied. This signified the favourability and suitability of the spent $R$. arrhizus biomass as a biosorbent for the removal of azo dyes under studied conditions.

The Freundlich isotherm model assumes heterogeneous sorption sites with different energies of sorption. The values of Freundlich constant $K_{\mathrm{F}}$ and $1 / n$, presented in Table 4, were obtained from the linear form of Freundlich isotherms ( $\log q$ against $\log$ Cf). Plot for mixed azo dyes is shown in Fig. 11. The values of $1 / n$ were found to be less than unity, indicating the favourable biosorption under studied conditions.

The high values of correlation coefficient $\left(R^{2}\right)$ from both the models described the sorption process satisfactory. The relatively high values of $R^{2}$ from Langmuir isotherms showed the best fit with this model and furnished monolayer maximum adsorption capacities 47.0, 108.8, 49.0, $33.8,128.5$, and $51.9 \mathrm{mg} / \mathrm{g}$ for dyes amaranth, fast red A, congo red, tartrazine, metanil yellow and sunset yellow

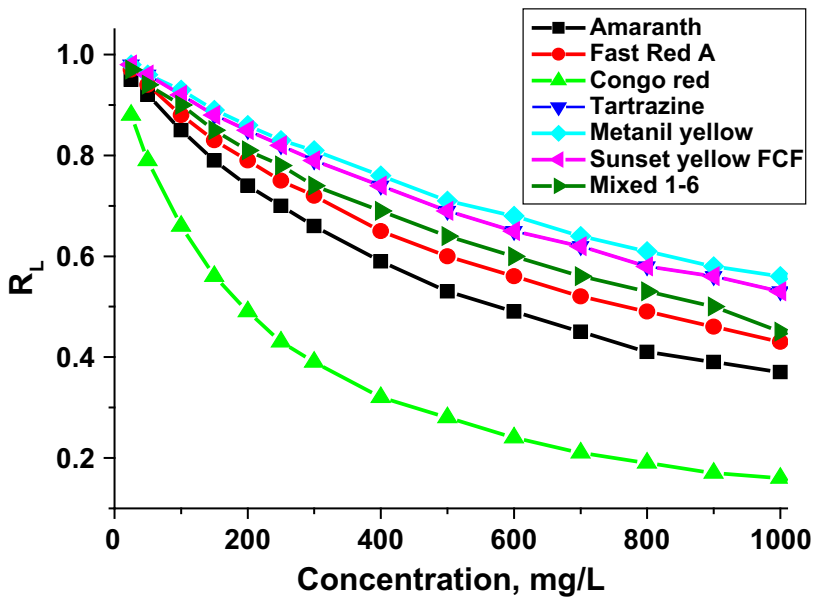

Fig. 10 Separation factor $\left(R_{\mathrm{L}}\right)$

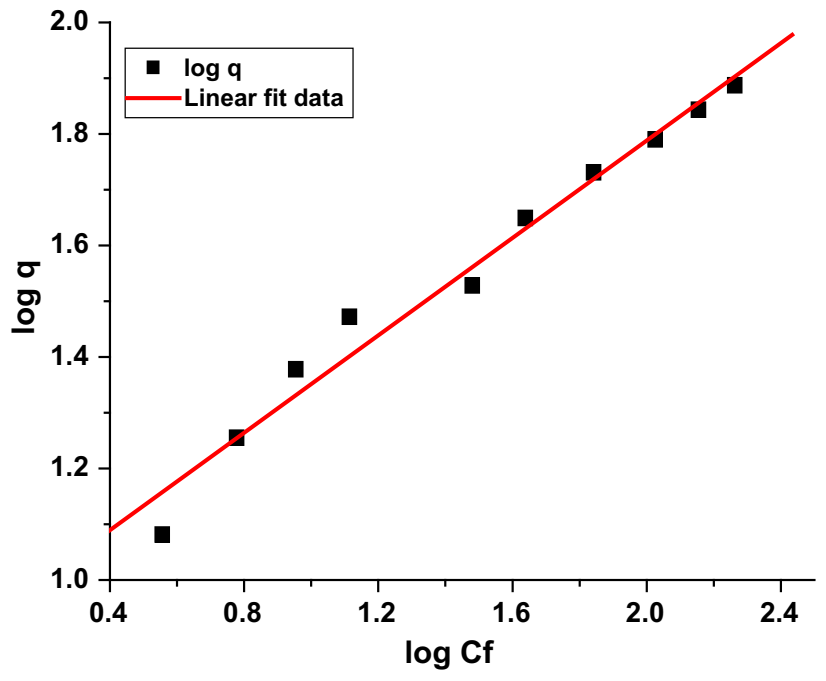

Fig. 11 Freundlich adsorption isotherm of mixed 1-6 azo dyes on spent $R$. arrhizus biomass

Table 4 Langmuir and Freundlich isotherm constants

\begin{tabular}{|c|c|c|c|c|c|c|}
\hline \multirow[t]{2}{*}{ Dyes } & \multicolumn{3}{|c|}{ Langmuir isotherm } & \multicolumn{3}{|c|}{ Freundlich isotherm } \\
\hline & $R^{2}$ & $q_{\max }, \mathrm{mg} / \mathrm{g}$ & $K_{\mathrm{L}}, \mathrm{L} / \mathrm{g}$ & $R^{2}$ & $K_{\mathrm{F}}, \mathrm{mg} / \mathrm{g}$ & $1 / n$ \\
\hline 1. Amaranth & 0.99888 & 47.0 & 0.0572 & 0.98416 & 13.7 & 0.1988 \\
\hline 2. Fast red 88 & 0.98475 & 108.8 & 0.0236 & 0.96575 & 16.5 & 0.3049 \\
\hline 3. Congo red & 0.99341 & 49.0 & 0.1140 & 0.97825 & 20.9 & 0.1489 \\
\hline 4. Tartrazine & 0.99520 & 33.8 & 0.0394 & 0.98978 & 7.8 & 0.2287 \\
\hline 5. Metanil yellow & 0.99269 & 128.5 & 0.0293 & 0.98593 & 6.4 & 0.6070 \\
\hline 6. Sunset yellow FCF & 0.99619 & 51.9 & 0.0352 & 0.98183 & 11.4 & 0.2414 \\
\hline 7. Mixed dyes 1-6 & 0.99719 & 76.4 & 0.0430 & 0.98813 & 8.2 & 0.4369 \\
\hline
\end{tabular}


FCF, respectively. The differences in the uptake capacities of azo dyes might be due to the differences in the structural properties of each dye. Thus, the ionic exchange and electrostatic attraction, structure of dye molecules and surface chemistry of fungal biomass could play an important role in dye biosorption on fungal biomass.

The dye effluents contain a range of dyes; the decolourization of a single dye does not adequately indicate the suitability of the biomass for wastewater treatment. Therefore, to simulate dye house effluent, multicomponent dye solution (mixed dyes 1-6) was subjected for decolourization using spent $R$. arrhizus biomass. The maximum sorption capacity of $76.4 \mathrm{mg} / \mathrm{g}$ is obtained for multicomponent dye solutions adsorbed onto spent $R$. arrhizus biomass. It is nothing but the approximate mean of the maximum adsorption capacity values of individual six dyes. This suggested a direct competition mechanism among dyes for adsorption on the biomass surface, and no dye is preferentially bound onto the biomass. A similar conclusion was reported in earlier studies on the adsorption of reactive dyes from aqueous solution onto oven-dried $R$. arrhizus biomass (O’Mahonya et al. 2002).

\section{Effect of salt concentration}

In general, dyes are applied to fabric in the presence of salt, mainly $\mathrm{NaCl}$, to lower the dye solubility (Karcher et al. 2001). Therefore, dye in wastewater is accompanied by a large amount of salt, which is likely to interfere with dye sorption. The effect of ionic strength $(\mathrm{NaCl}$ concentration, $0-5 \%, w / v)$ on the biosorption of azo dyes is shown in Fig. 12. The marginal reduction in the colour removal

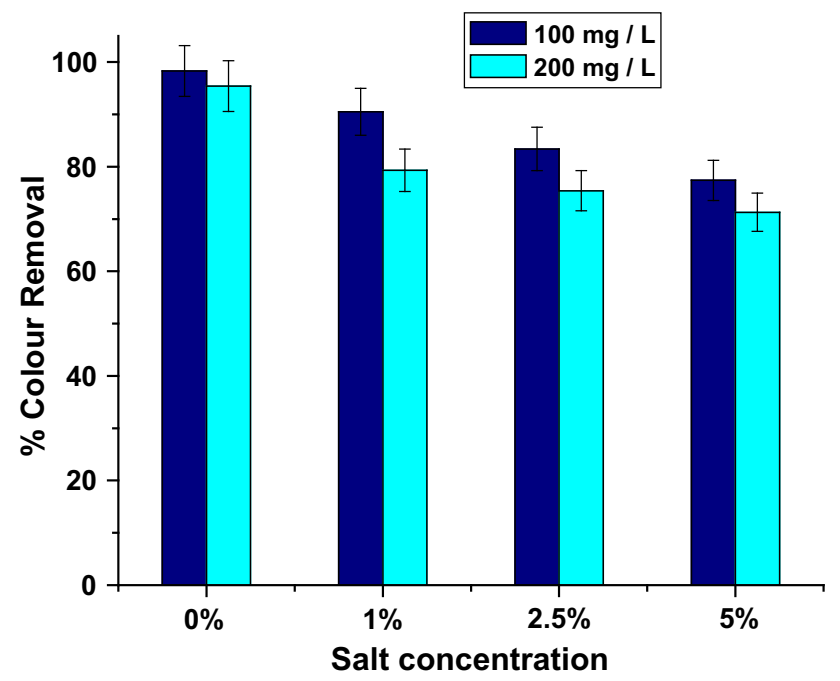

Fig. 12 Effect of salt concentration on the adsorption of mixed 1-6 dye solution by spent $R$. arrhizus biomass [conditions: biomass dose (200 mg/25 mL dye solution), agitation time (120 min), agitation speed $(100 \mathrm{rpm})$, ambient temperature, natural $\mathrm{pH}$ ]

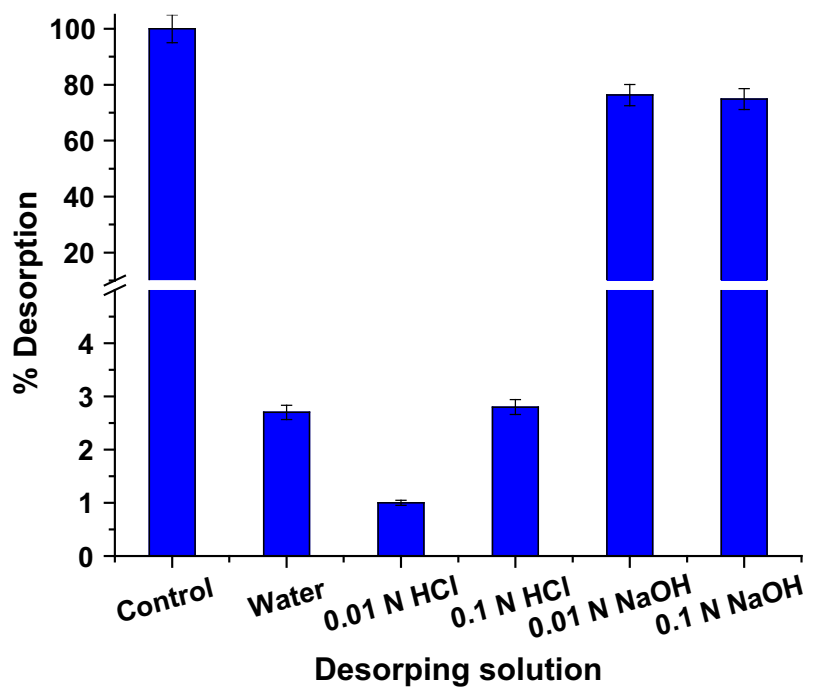

Fig. 13 Desorption studies [conditions: mixed 1-6 dye concentration (control $100 \mathrm{mg} / \mathrm{L}$ ), biomass dose $(200 \mathrm{mg} / 25 \mathrm{~mL}$ dye solution), desorbing solution ( $25 \mathrm{~mL} /$ flask), agitation time (15 min), agitation speed (100 rpm), ambient temperature]

efficiency was seen. It was noted that an elevated ionic strength due to $\mathrm{NaCl}$ did not significantly interfere the binding of dye molecules to adsorption sites on the biomass. From a practical point of view, these results implied that the waste $R$. arrhizus biomass could be used for the removal of dyes from salt-containing wastewaters.

\section{Desorption studies}

Desorption studies helps to elucidate the mechanism of adsorption. It was found that the negligible amount of dye was desorbed with distilled water and acidic solutions. However, $<75 \%$ of dye was desorbed with $0.01 \mathrm{~N} \mathrm{NaOH}$, which did not change significantly with $0.1 \mathrm{~N} \mathrm{NaOH}$ (Fig. 13). The release of dye from the biomass with aqueous alkaline medium was easy and opposite to that of $\mathrm{pH}$ effect. The adsorption of dyes in an acidic medium and desorption in an alkaline medium showed that the ion exchange might be the major mode of adsorption. Desorption at higher $\mathrm{pH}$ may be explained on the basis of electrostatic repulsion between the negatively charged sites on the fungal biomass and the anionic dye molecules (Namasivayam et al. 1996, 2001).

\section{Comparison of adsorption capacity with other biosorbents}

The adsorption capacities of azo dyes reported in this study were compared with several others biosorbents and summarized in Table 5. The different adsorption capacities 
Table 5 Adsorption capacities of azo dyes with other biosorbents

\begin{tabular}{|c|c|c|c|c|}
\hline Dye & Biosorbent & $q, \mathrm{mg} / \mathrm{g}$ & Experimental conditions & References \\
\hline \multirow[t]{4}{*}{ Amaranth } & Rhizopus arrhizus & 47.0 & Natural $\mathrm{pH}$ and ambient temp. & This work \\
\hline & Water hyacinth leaves & 70.0 & $\mathrm{pH} 2$ and $18{ }^{\circ} \mathrm{C}$ & Guerrero-Coronilla et al. (2015) \\
\hline & Papaya seeds & 37.4 & $\mathrm{pH} 2.5,25^{\circ} \mathrm{C}$ & Weber et al. (2014) \\
\hline & Tamarind pod shells & 65.04 & $\mathrm{pH} 2$ & Naidu et al. (2012) \\
\hline \multirow[t]{5}{*}{ Acid red 88} & Rhizopus arrhizus & 108.8 & Natural $\mathrm{pH}$ and ambient temp. & This work \\
\hline & Ulva reticulata & 16.54 & pH 7 & Saravanan (2014) \\
\hline & Azolla pinnata & 53.76 & $\mathrm{pH} 3,30^{\circ} \mathrm{C}$ & $\begin{array}{l}\text { Vijayaraghavan and Padmesh } \\
\text { (2008) }\end{array}$ \\
\hline & Azolla rongpong & 78.74 & $\mathrm{pH} 2.5,35^{\circ} \mathrm{C}$ & Padmesh et al. (2006) \\
\hline & Azolla filiculoides & 123.5 & $\mathrm{pH} 7.0,0.1 \mathrm{M} \mathrm{HCl}$ treated biomass & Padmesh et al. (2005) \\
\hline \multirow[t]{10}{*}{ Congo red } & Rhizopus arrhizus & 49.0 & Natural pH and ambient temp. & This work \\
\hline & Bacterial Dietzia strain & 170.34 & $\mathrm{pH} 3,40^{\circ} \mathrm{C}$ & Saha et al. (2013) \\
\hline & Saccharum bengalense & 125 & $\mathrm{pH} 2,50^{\circ} \mathrm{C}$ & Din et al. (2013) \\
\hline & Powdered eggshell & 95.25 & pH 2 & Zulfikar and Setiyanto (2013) \\
\hline & Indian Jujuba seeds & 55.56 & $\mathrm{pH} 2$ & Reddy et al. (2012) \\
\hline & PenicilliumYW 01 & 411.53 & $\mathrm{pH} 3,40^{\circ} \mathrm{C}$ & Yang et al. (2011) \\
\hline & Sugarcane bagasse & 38.20 & $\mathrm{pH} 5$, ball-milled & Zhang et al. (2011) \\
\hline & Untreated Tendu waste & 46.95 & pH 6.2 & Nagda and Ghole (2009) \\
\hline & Hydrogen peroxide treated tendu waste & 134.4 & & \\
\hline & Mycelial pellets of Trametes versicolor & 51.81 & $\mathrm{pH} \mathrm{2,} \mathrm{autoclaved}$ & Binupriya et al. (2008) \\
\hline \multirow[t]{3}{*}{ Tartrazine } & Rhizopus arrhizus & 33.8 & Natural pH and ambient temp. & This work \\
\hline & Papaya seeds & 51.0 & $\mathrm{pH} 2.5,25^{\circ} \mathrm{C}$ & Weber et al. (2014) \\
\hline & Spirulina platensis & 363.2 & Sips model, $25^{\circ} \mathrm{C}$ & Dotto et al. (2013) \\
\hline \multirow[t]{4}{*}{ Metanil yellow } & Rhizopus arrhizus & 128.5 & Natural pH and ambient temp. & This work \\
\hline & Immobilized aquatic weed & 9.91 & pH 6 & Sathya et al. (2013) \\
\hline & Bottom ash & 4.77 & $\mathrm{pH} 2,30^{\circ} \mathrm{C}$ & Mittal et al. (2008) \\
\hline & De-oiled soya & 3.66 & $\mathrm{pH} 2,30^{\circ} \mathrm{C}$ & Mittal et al. (2008) \\
\hline \multirow[t]{3}{*}{ Sunset yellow FCF } & Rhizopus arrhizus & 51.9 & Natural pH and ambient temp. & This work \\
\hline & Powdered peanut hull & 13.99 & pH 2 & Gong et al. (2005) \\
\hline & Mangrove bark $\mathrm{HCHO}$ treated & 12.72 & pH 2 & Seey and Kassim (2012) \\
\hline
\end{tabular}

showed the dependence on the properties of individual adsorbent and the structural variation of the dye.

From Table 5, it was observed that in most of the reported studies, the maximum sorption capacity of these six azo dyes was obtained at acidic $\mathrm{pH}$ (between 2 and 3 ) and sometimes at different temperatures. However, this communication represents the sorption at natural $\mathrm{pH}$ of dye solution and ambient temperature. Spent $R$. arrhizus biomass furnished maximum sorption capacity for dye metanil yellow (128.5 mg/g) and dye sunset yellow FCF (51.9 mg/ g). Tamarind pod shells at $\mathrm{pH} 2$ showed $65.04 \mathrm{mg} / \mathrm{g}$ maximum sorption capacity for dye amaranth, whereas spent biomass showed $47.0 \mathrm{mg} / \mathrm{g}$ at natural $\mathrm{pH}$. In the case of dye acid red $88,0.1 \mathrm{M} \mathrm{HCl}$ treated Azolla filiculoides biomass gave maximum sorption capacity $(123.5 \mathrm{mg} / \mathrm{g})$, while spent biomass showed $108.8 \mathrm{mg} / \mathrm{g}$ at natural $\mathrm{pH}$ and ambient temperature. Similarly, for dye congo red, Penicillium YW 01 and Bacterial Dietzia strain provided maximum adsorption capacity 411.53 and $170.34 \mathrm{mg} / \mathrm{g}$, respectively, at $\mathrm{pH} 3$ and $40{ }^{\circ} \mathrm{C}$. Hydrogen peroxide treated tendu waste furnished $134.4 \mathrm{mg} / \mathrm{g}$ and that of powdered eggshell provided $95.25 \mathrm{mg} / \mathrm{g}$ maximum sorption at $\mathrm{pH} 2$. The untreated tendu waste showed $46.95 \mathrm{mg} / \mathrm{g}$ maximum sorption capacity at $\mathrm{pH} 6.2$ which is comparable with that of sorption capacity with spent $R$. arrhizus biomass $(49.0 \mathrm{mg} / \mathrm{g}$ ) at natural $\mathrm{pH}$ and ambient temperature. For dye tartrazine, papaya seeds showed $51.0 \mathrm{mg} / \mathrm{g}$ maximum sorption capacity at $\mathrm{pH} 2.5$, whereas spent biomass gave $33.8 \mathrm{mg} / \mathrm{g}$ maximum sorption capacity at natural $\mathrm{pH}$ and ambient temperature.

Thus, easily available spent $R$. arrhizus biomass has decolourization capability for the broad range of azo dyes 
under natural conditions with easy operation. The utilization of normal conditions for biosorption studies cannot be avoided for all practical reasons with respect to the scaling of the technology.

\section{Conclusion}

The present communication describes the biosorption of six azo dyes and their multicomponent solutions using spent $R$. arrhizus biomass. The efficiency of the biomass was evaluated by varying the contact time, adsorbent dose, $\mathrm{pH}$ and initial dye concentration, and it was found to have an effect on the dye uptake capacity of the biomass. The biosorption process followed a much better fit with the pseudo-second-order kinetic model with the correlation coefficient near unity. The analysis of the equilibrium experimental data by both Langmuir and Freundlich isotherm models indicated a positive adsorption. The equilibrium data fitted very well with the Langmuir adsorption isotherm, suggesting the monolayer coverage of dyes under the experimental conditions. The biomass had the ability to tolerate the presence of a co-pollutant, such as salt, and was also effective at lower dye concentration. The FTIR spectra and optical microscopic images of adsorbents are in support of the results obtained. The decolourization of multicomponent solution of these dyes mimics a dye house effluent, showing the practical utility of the process.

The novelty of this investigation is that it was carried out at the natural $\mathrm{pH}$ values of the dye solutions and at ambient temperatures using spent $R$. arrhizus biomass. This report could prove to be one of the initial documented evidences to exhibit the development and implementation of cost-effective method for the removal of azo dyes from industrial effluents using waste material. The process can also be easily scalable for all practical applications.

Acknowledgments The corresponding author extends sincere thanks to Mrs Varsha More, Food Technology Division, Bhabha Atomic Research Centre for her valuable technical help and also to Dr Hema Rajaram and $\mathrm{Mr}$ Akhilesh Potnis, Molecular Biology Division, Bhabha Atomic Research Centre for their help in recording the optical microscopic images.

Open Access This article is distributed under the terms of the Creative Commons Attribution 4.0 International License (http://creativecommons.org/licenses/by/4.0/), which permits unrestricted use, distribution, and reproduction in any medium, provided you give appropriate credit to the original author(s) and the source, provide a link to the Creative Commons license, and indicate if changes were made.

\section{References}

Aksu Z, Kilic NK, Ertugrul S, Donmez G (2007) Inhibitory effects of chromium (VI) and remazol black B on chromium (VI) and dyestuff removals by Trametes versicolor. Enzyme Microb Technol 40:1167-1174

Anjaneya O, Souche SY, Santoshkumar M, Karegoudar TB (2011) Decolorization of sulfonated azo dye metanil yellow by newly isolated bacterial strains: Bacillus sp. strain AK1 and Lysinibacillus sp. strain AK2. J Hazard Mater 190:351-358

Anjaneya O, Shrishailnath SS, Guruprasad K, Nayak AS, Mashetty SB, Karegoudar TB (2013) Decolourization of amaranth dye by bacterial biofilm in batch and continuous packed bed bioreactor. Int Biodeterior Biodegrad 79:64-72

Arami M, Yousefi Limee N, Mahmoodi NM, Salman Tabrizi N (2006) Equilibrium and kinetics for the adsorption of direct acid dyes from aqueous solution by soy meal hull. J Hazard Mater B135:171-179

Avramescu SM, Mihalache N, Bradu C, Neata M, Udrea I (2009) Catalytic ozonation of acid red 88 from aqueous solutions. Catal Lett 129(3):273-280

Bhatia MS (2000) Allergy to tartrazine in psychotropic drugs. J Clin Psychiatry 61(7):473-476

Bhattacharyya KG, Sharma A (2004) Azadirachta indica leaf powder as an effective biosorbent for dyes: a case study with aqueous Congo red solutions. J Environ Manag 71:217-229

Bhatti HN, Sadaf S, Aleem A (2015) Treatment of textile effluents by low cost agricultural wastes: Batch Biosorption Study. J Anim Plant Sci 25(1):284-289

Binupriya AR, Sathishkumar M, Swaminathan K, Ku CS, Yun SE (2008) Comparative studies of removal of congo red by native and modified mycelial pellets of Trametes versicolor in various reactor modes. Bioresour Technol 99:1080-1088

Blackburn RS (2004) Natural polysaccharides and their interactions with dye molecules: applications in effluent treatment. Environ Sci Technol 38:4905-4909

Chandro SS, Nagaraja T (1987) A food-poisoning out-break with chemical dye. An investigation report. Med J Armed Forces India 43:291-300

Couto SR (2009) Dye removal by immobilised fungi. Biotechnol Adv 27:227-235

Crini G (2006) Non-conventional low-cost adsorbents for dye removal: a review. Bioresour Technol 97:1061-1085

Das M, Ramchandani S, Upreti RK, Khanna SK (1997) Metanil yellow: a biofunctional inducer of hepatic phase I and phase II xenoblasticmetabolising enzymes. Food Chem Toxicol 35:835-838

Demirbas A (2009) Agricultural based activated carbons for the removal of dyes from aqueous solutions. J Hazard Mater 167(1-3):1-9

Dhami PS, Gopoalakrishnan V, Kannan R, Ramanujam A, Salvi NA, Udupa SR (1998a) Biosorption of radionuclides by Rhizopus arrhizus. Biotechnol Lett 20:225-228

Dhami PS, Kannan R, Gopoalakrishnan V, Ramanujam A, Salvi NA, Udupa R (1998b) Sorption of plutonium, americium and fission products from reprocessing effluents using Rhizopus arrhizus. Biotechnol Lett 20:869-872

Dhami PS, Kannan R, Naik PW, Gopoalakrishnan V, Ramanujam A, Salvi NA, Chattopadhyay S (2002) Biosorption of americium using biomasses of various Rhizopus species. Biotechnol Lett 24:885-889

Din MI, Hussain Z, Mirza ML, Athar MM, Madni A, Saeed A (2013) Biosorption of toxic congo red dye from aqueous solution by eco-friendly biosorbent Saccharum bengalense: kinetics and thermodynamics. Desalination Water Treat 51:5638-5648

Dotto GL, Vieira MLG, Esquerdo VM, Pinto LAA (2013) Equilibrium and thermodynamics of azo dyes biosorption onto Spirulina platensis. Braz J Chem Eng 30:13-21

Farah JY, El-Gendy NS, Farahat LA (2007) Biosorption of astrazone blue basic dye from an aqueous solution using dried biomass of Baker's yeast. J Hazard Mater 148:402-408 
Foletto EL, Weber CT, Paz DS, Mazutti MA, Meili L, Bassaco MM, Collazzo GC (2012) Adsorption of leather dye onto activated carbon prepared from bottle gourd: equilibrium, kinetic and mechanism studies. Water Sci Technol 67:201-209

Freundlich H, Heller W (1939) The adsorption of cis- and transazobenzene. J Am Chem Soc 61:2228-2230

Garg VK, Gupta R, Yadav AB, Kumar R (2003) Dye removal from aqueous solution by adsorption on treated sawdust. Bioresour Technol 89:121-124

Gautam PK, Banerjee S, Rawat V, Soni S, Sharma SK, Chattopadhyaya MC (2015) Removal of tartrazine by activated carbon biosorbents of Lantana camara: kinetics, equilibrium modeling and spectroscopic analysis. J Environ Chem Eng 3(1):79-88

Gong R, Ding Y, Li M, Yang C, Liu H, Sun Y (2005) Utilization of powdered peanut hull as biosorbent for removal of anionic dyes from aqueous solution. Dyes Pigm 64:187-192

Guerrero-Coronilla I, Morales-Barrera L, Cristiani-Urbina E (2015) Kinetic, isotherm and thermodynamic studies of amaranth dye biosorption from aqueous solution onto water hyacinth leaves. J Environ Manag 152:99-108

Gupta V, Suhas K (2009) Application of low-cost adsorbents for dye removal: a review. J Environ Manag 90:2313-2342

Gupta S, Sundarrajan M, Rao KVK (2003) Tumour promotion by metanil yellow and malachite green during rat hepatocarcinogenesis is associated with dysregulated expression of cell cycle regulatory proteins. Teratogenetic Carcinogenetic Mutat 23(Suppl. 1):301-312

Hai FI, Yamamoto K, Fukushi K (2007) Hybrid treatment systems for dye wastewater. Environ Sci Technol 37:315-377

Hamdaoui O, Saoudi F, China ME (2008) Naffrechoux, sorption of malachite green by a novel sorbent, dead leaves of plane tree: equilibrium and kinetic modeling. Chem Eng J 143:73-84

Hausen BM (1994) A case of allergic contact dermatitis due to Metanil Yellow. Contact Dermatis 31:117-118

Ho YS, McKay G (1999) Pseudo-second order model for sorption processes. Process Biochem 34:451-465

Ho YS, Wang CC (2004) Pseudo-isotherms for the sorption of cadmium ion onto tree fern. Process Biochem 39:761-765

Jabeen HS, Rahman SU, Mahmood S, Anwer S (2013) Genotoxicity assessment of amaranth and allura red using Saccharomyces cerevisiae. Bull Environ Contam Toxicol 90:22-26

Jadhav SB, Patil NS, Watharkar AD, Apine OA, Jadhav JP (2013) Batch and continuous biodegradation of amaranth in plain distilled water by $P$. Aeruginosa $\mathrm{BCH}$ and toxicological scrutiny using oxidative stress studies. Environ Sci Pollut Res 20:2854-2866

Jin B, Yin P, Ma Y, Zhao L (2005) Production of lactic acid and fungal biomass by Rhizopus fungi from food processing waste streams. J Ind Microbiol Biotechnol 32(11-12):678-686

Kapoor A, Viraraghavan T (1998) Heavy metal biosorption sites in Aspergillus niger. Bioresour Technol 61:221-227

Karcher S, Kornmüller A, Jekel M (2001) Screening of commercial sorbents for the removal of reactive. Dyes Pigments 51:111-125

Karkmaz M, Puzenat E, Guillard C, Herrmann JM (2004) Photocatalytic degradeation of the alimentary azo dye amaranth: mineralization of the azo group to nitrogen. Appl Catal B $51: 183-194$

Lagergren S (1898) About the theory of so-called adsorption of soluble substance. Kungliga Svenska Vetenskapsakademiens Handlingar. 24:1-39

Langmuir I (1918) The adsorption of gases on plane surface of glass, mica and platinum. J Am Chem Soc 40:1361-1403

Lockey SD (1977) Hypersensitivity to tartrazine (FD \& C yellow No.5) and other dyes and additives present in foods and pharmaceutical products. Ann Allergy 38:206-210
Maas R, Chaudhari S (2005) Adsorption and biological decolourization of azo dye-reactive red 2 in semicontinuous anaerobic reactors. Process Biochem 40:699-705

Mall ID, Srivastava VC, Agarwal NK, Mishra IM (2005) Removal of congo red from aqueous solution by bagasse fly ash and activated carbon: kinetic study and equilibrium isotherm analysis. Chemosphere 61:492-501

McKay G, Blair HS, Gardener JR (1982) Adsorption of dyes on chitin. I. Equilibrium studies. J Appl Polym Sci 27:3043-3057

Mittal A, Gupta VK, Malviya A, Mittal J (2008) Process development for the batch and bulk removal and recovery of a hazardous, water-soluble azo dye (metanil yellow) by adsorption over waste materials (bottom ash and de-oiled soya). J Hazard Mater 151:821-832

Moutinho ILD, Bertges LC, Assis RVC (2007) Prolonged use of the food dye tartrazine and its effects on the gastric mucosa of Wistar rats Braz. J Biol 67:141-145

Nagda GK, Ghole VS (2009) Biosorption of congo red by hydrogen peroxide treated tendu waste. J Environ Health Sci Eng 6(3):195-200

Naidu A, Chadraprabha MN, Kanamadi RD, Ramachandra TV (2012) Adsorption of methylene blue and amaranth on to tamarind pod shells. J Biochem Technol. 3(5):S189-S192

Namasivayam C, Muniasamy N, Gayathri K, Rani M, Ranganathan K (1996) Removal of dyes from aqueous solutions by cellulosic waste orange peel. Bioresour Technol 57:37-43

Namasivayam C, Radhika R, Sub S (2001) Uptake of dyes by a promising locally available agricultural solid waste: coir pit. Waste Manag 21:381-387

O'Mahonya T, Guibalb E, Tobina JM (2002) Reactive dye biosorption by Rhizopus arrhizus biomass. Enzyme Microb Technol 31(4):456-463

Olukanni OD, Osuntoki AA, Gbenle GO (2009) Decolourization of azo dyes by strain of Micrococcus isolated from a refuse dump soil. Biotechnology 8:442-448

Padmesh TVN, Vijayaraghavan K, Sekaran Velan GM (2005) Batch and column studies on biosorption of acid dyes on fresh water macro alga Azolla filiculoides. J Hazard Mater B125:121-129

Padmesh TVN, Vijayaraghavan K, Sekaran Velan GM (2006) Application of Azolla rongpong on biosorption of acid red 88, acid green 3, acid orange 7 and acid blue 15 from synthetic solutions. Chem Eng J 122:55-63

Pavan FA, Dias SLP, Lima EC, Benvenutti EV (2008) Removal of congo red from aqueous solution by anilinepropylsilica xerogel. Dyes Pigments 76:64-69

Peiperl MD, Prival MJ, Bell SJ (1995) Determination of combined benzidine in FD\&C yellow no. 6 (sunset yellow FCF). Food Chem Toxicol 33:829-839

Perez-Urquiza M, Beltran JL (2000) Determination of dyes in foodstuffs by capillary zone electrophoresis. J Chromatogr A 898:271-275

Pohl R, Balon R, Berchou R, Yeragani VK (1987) Allergy to tartrazine in antidepressants. Am J Psychiatry 144:237-238

Poul M, Jarry G, Elhkim MO, Poul JM (2009) Lack of genotoxic effect of food dyes amaranth, sunset yellow and tartrazine and their metabolites in the gut micronucleus assay in mice. Food Chem Toxicol 47:443-448

Ramachandani S, Das M, Joshi A, Khanna SK (1997) Effect of oral and parental administration of metanil yellow on some hepatic and intestinal biochemical parameters. J Appl Toxicol 17:85-91

Reddy MCS, Sivaramakrishna L, Varada Reddy A (2012) The use of an agricultural waste material, Jujuba seeds for the removal of anionic dye (congo red) from aqueous medium. J Hazard Mater 203-204:118-127 
Sachdeva SM, Mani KV, Adval SK, Jalpota VP, Rasela KC, Chadha DS (1992) Acquired toxic methaemoglobinaemia. J Assoc Physicians Ind 40:239-240

Sadafa S, Bhatti HN (2016) Response surface methodology approach for optimization of adsorption process for the removal of indosol yellow BG dye from aqueous solution by agricultural waste. Desalination Water Treat 57(25):11773-11781

Sadafa S, Bhattia HN, Arifb M, Amina M, Nazarc Farva (2015a) Adsorptive removal of direct dyes by PEI-treated peanut husk biomass: Box-Behnken experimental design. Chem Ecol 31(3):252-264

Sadafa S, Bhattib HN, Nausheenb S, Aminb M (2015b) Application of a novel lignocellulosic biomaterial for the removal of direct yellow 50 dye from aqueous solution: batch and column study. J Taiwan Inst Chem Eng 47:160-170

Saha PD, Bhattacharya P, Sinha K, Chowdhury S (2013) Biosorption of congo red and indigo carmine by nonviable biomass of a new Dietzia strain isolated from the effluent of a textile industry. Desalination Water Treat 51:5840-5847

Salvi NA, Chattopadhyay S (2008) Asymmetric reduction of halosubstituted arylalkanones with Rhizopus arrhizus. Tetrahedron Asymmetry 19:1992-1997

Salvi NA, Chattopadhyay S (2011) Rhizopus arrhizus-mediated asymmetric reduction of arylalkanones: unusual anti-Prelong products with benzyl alkyl ketones. Tetrahedron Asymmetry 22:1512-1515

Saravanan A (2014) Equilibrium and kinetic modeling of acid red 88(AR88) biosorption by Ulva reticulate. Int J Chem Process Eng Res 1:19-31

Sathya AB, Sivashankar R, Pallipad S, Sivasubramanian V (2013) Biosorption of hazardous azo dye metanil yellow using immobilized aquatic weed. In: International conference on Future Trends in Structural, Civil, Environmental and Mechanical Engineering-FTSCEM, pp 153-157

Seey TL, Kassim NJNM (2012) Acidic and basic dyes removal by adsorption on chemically treated mangrove barks. Int J Appl Sci Technol 2:270-276

Shahmoradi B, Maleki A, Byrappa K (2011) Photocatalytic degradation of amaranth and brilliant blue FCF dyes using in situ modified tungsten doped $\mathrm{TiO} 2$ hybrid nanoparticles. Catal Sci Technol 1:1216-1223

Stolz A (2001) Basic and applied aspects in the microbial degradation of azo dyes. Appl Microbiol Biotechnol 56:69-80

Sudha Bai RT, Abraham E (2001) Biosorption of Cr(VI) from aqueous solution by Rhizopus nigricans. Bioresour Technol 79:73-81

Supaka N, Juntongijin K, Damronglerd S, Delia ML, Strehaiano P (2004) Microbial decolorization of reactive azo dyes in a sequential anaerobic-aerobic system. Chem Eng J 99:169-176

Swamy J, Ramsay JA (1999) The evaluation of white rot fungi in the decoloration of textile dyes. Enzyme Microb Technol 24:130-137
Tigini V, Prigione V, Donelli I, Anastasi A, Freddi G, Giansanti P, Mangiavillano A, Varese GC (2011) Cunninghamella elegans biomass optimisation for textile wastewater biosorption treatment: an analytical and ecotoxicological approach. Appl Microbiol Biotechnol 90:343-352

Tripathi SC, Kannan R, Dhami PS, Naik PW, Munshi SK, Dey PK, Salvi NA, Chattopadhyay S (2011) Modified Rhizopus arrhizus biomass for sorption of ${ }^{241} \mathrm{Am}$ and other radionuclides. J Radioanal Nucl Chem 287:691-695

Vijayaraghavan K, Padmesh TVN (2008) Biosorption of acid red 88 onto Azolla pinnata: equilibrium and kinetic studies. Int J Appl Bioeng 2(1):15-20

Wang J, Chen C (2009) Biosorbents for heavy metals removal and their future. Biotechnol Adv 27:195-226

Weber WJ, Morris JC (1962) Kinetics of adsorption on carbon from solution. J Sanit Eng Div ASCE 89:31-59

Weber CT, Collazzo GC, Mazutti MA, Foletto EL, Dotto GL (2014) Removal of hazardous pharmaceutical dyes by adsorption onto papaya seeds. Water Sci Technol 70:102-107

Wu F-C, Tseng R-L, Juang R-S (2000) Comparative adsorption of metal and dye on flake-and bead-types of chitosans prepared from fishery wastes. J Hazard Mater B73:63-75

Yang Y, Wang G, Wang B, Li Z, Jia X, Zhou Q, Zhao Y (2011) Biosorption of acid black 172 and congo red from aqueous solution by nonviable penicillium YW 01: kinetic study, equilibrium isotherm and artificial neural network modeling. Bioresour Technol 102:828-883

Yang F, Song X, Yan L (2013) Preparation of cationic waste paper and its application in poisonous dye removal. Water Sci Technol 67:2560-2567

Yu X, Zhang G, Xi C, Yu Y, Cheng T, Zhou Q (2011) Equilibrium, kinetic, and thermodynamic studies of hazardous dye neutral red biosorption by spent corncob substrate. BioResources 6(2):936-949

Zaharia C, Suteu D, Muresan A (2012) Options and solutions for textile effluent decolorization using some specific physicochemical treatment steps. Environ Eng Manag J 11(2):493-509

Zhan Y, Lin J, Li J (2013) Preparation and characterization of surfactant-modified hydroxyapatite/zeolite composite and its adsorption behaviour toward humic acid and copper(II). Environ Sci Pollut Res 20(4):2512-2526

Zhang G, Ma Y (2013) Mechanistic and conformational studies on the interaction of food dye amaranth with human serum albumin by multispectroscopic methods. Food Chem 136:442-449

Zhang Z, Moghaddam L, O'Hara IM, Doherty WOS (2011) Congo Red adsorption by ball-milled sugarcane bagasse. Chem Eng J 178:122-128

Zulfikar MA, Setiyanto H (2013) Adsorption of congo red from aqueous solution using powdered eggshell. Int J Chem Technol Res CODEN(USA) 5(4):1532-1540 